\title{
Usability of Some Reactive Dyes in Human Blood Cells (HBCs) Staining
}

\author{
Nilgun Guler Kusculu (Corresponding author) \\ Kayseri University, Mustafa Cikrikcioglu Vocational School, Kayseri, Turkey \\ E-mail:nguler@erciyes.edu.tr \\ Huseyin Benli \\ Kayseri University, Mustafa Cikrikcioglu Vocational School, Kayseri, Turkey \\ E-mail: hbenli@erciyes.edu.tr
}

\begin{abstract}
The application of Remazol dyes as a synthetic dye for textiles has been known for a long time; in addition, some synthetic dyes are also used for staining histological sections. These dyes have different chemical structures but they have the same chemical bonding principle with materials like cells or textiles. The aim of this study is to determine for Human Blood Cells (HBCs) through dyeing with some reactive dyes. For this purpose, we used four Remazol dyes of different colors like Rot R, Dark Blue, Schwarz RL, and Blue BB. Application of these dyes to HBCs on slides carried out at different times like $15,30,45$, and 60 minutes and altering temperatures like $25^{\circ} \mathrm{C}, 60^{\circ} \mathrm{C}$, and $100^{\circ} \mathrm{C}$, respectively. The slides were then washed with distilled water, air dried and viewed at 1000 magnification by light microscopy (Leica microsystems D30). As a result, we found that, HBCs were dyed in pale and light color by all Remazol dyes at $100^{\circ} \mathrm{C}$ for 60 minutes with soda-sulfate mordant. HBCs partially denaturated at all temperatures and times. However, HBCs were dyed a darker red color at $100^{\circ} \mathrm{C}$ for 60 minutes by Remazol Rot R and alum. We conclude that Remazol Rot R, Dark Blue, Schwarz RL, and Blue BB dyes have potential for dyeing $\mathrm{HBCs}$ with alum at $100^{\circ} \mathrm{C}$ for 60 minutes.
\end{abstract}

Keywords: Human Blood Cells, Histological stains, Reactive dyes, Remazol, Textiles, Synthetic dyes

DOI: $10.7176 / \mathrm{JSTR} / 5-2-07$

\section{Introduction}

Manufacture and use of synthetic dyes for fabric dyeing has become a massive industry today. In fact the art of applying color to fabric has been known to mankind since 3500 BC. Perkins in 1856 discovered the use of synthetic dyes ${ }^{1}$. During the past decades, textile industry has played an important role in economic growth of some countries, which was accompanied with the extensive use of various synthetic dyes, including Remazol Brillant Blue R, Orange I, Malachite Green Chloride, Indigo Carmine, and Rhodamine $\mathrm{B}^{2,3}$

There are different types of dyes available which are used according to specific as per need. Generally, basic dyes are applied on jute, acid dye on wool, reactive or vat dyes on cotton and disperse dye on manmade fibers ${ }^{4,5}$. Seven Remazol dyes, which bear the reactive substituent $\mathrm{SO}_{2} \mathrm{CH}_{2} \mathrm{CH}_{2} \mathrm{OSO}_{3} \mathrm{Na}$, were converted into related compounds with $\mathrm{SO}_{2} \mathrm{CH}_{2} \mathrm{CH}_{2} \mathrm{SSO}_{3} \mathrm{Na}$ substituents. When applied to wool from boiling dye baths acidified with sulfuric acid, these dyes which are called Buntazol dyes, give dyeings with slightly better wash fastness than the corresponding Remazols, which undergo covalent reaction with the fiber to a lesser extent ${ }^{6}$.

The characteristic features of a typical reactive dye includes i) a reactive system which enables the dye to form covalent bonds with the - $\mathrm{OH}$ group in the cellulose, with $-\mathrm{NH}_{2},-\mathrm{OH}$ and $-\mathrm{SH}$ groups in proteins fibers and with $-\mathrm{NH}_{2}$ group in polyamides, ii) a chromophoric group (s) which contributes to the color and the substantivity for the fiber, iii) a bridging group that links the reactive system with the chromophore and iv) solubilizing groups ${ }^{7,8}$. It is well known that the application of reactive dyes on 
cellulose fibers is carried out under highly alkaline conditions ${ }^{9}$. Synthetic dyes have also used for different areas from textile, such as food, medicine, biology, pharmacology.

Sudan I, II and III dyes are occasionally called for as a lipid stain in histology ${ }^{10}$. The staining of tissue sections was much influenced by aniline dye chemistry in the second half of the $19^{\text {th }}$ century. Ehrlich was among the first to systematically study synthetic dyes and to introduce scientific methods into the field of histological dye staining ${ }^{11,12}$. Histological staining is usually done by the staining of cut sections in as much as a dye in solution is used to bind to the defined tissue structures. Progressive and regressive techniques can be differentiated and include direct and indirect procedures ${ }^{13}$.

The term mordant is used for chemicals which usually have a metal with a valence of at least two or more, there are also other types of compounds as well. An alkali mordant, such as soda ash, works well with cotton, and an acid mordant such as vinegar works well with wool ${ }^{14,15}$. In this study, we carried out to do histological staining so that, we used reactive-Remazol dyes of different colors with different agents, mordant, temperatures and dyeing period to dye HBCs. Because, we had thought that there was a relationship between the proteins in cell molecules with reactive dyes and the proteins in wool with reactive dyes.

\section{Materials and methods}

\subsection{Chemicals and materials}

Reference reactive Remazol dyes, Rot R, Dark Blue, Schwarz RL and Blue BB, which were of technical grade, were obtained from the Dystar Company. Sodium carbonate $\left(\mathrm{Na}_{2} \mathrm{CO}_{3}\right)$, alum $\left(\mathrm{KAl}\left(\mathrm{SO}_{4}\right)_{2} .12 \mathrm{H}_{2} \mathrm{O}\right)$ and sodium sulfate $\left(\mathrm{Na}_{2} \mathrm{SO}_{4}\right)$ were obtained from Merck. HBCs samples were taken from a 20 year old, healthy female student.

Since this study included molecular interaction between blood cells and dyestuff and the results of the study will not be used for clinical purposes. So that, peripheral blood sample was taken from only one person's finger.

\subsection{Methods}

\subsubsection{Preparation of dye bath}

A $0.1 \%$ (v/v) dye bath, containing $0.1 \mathrm{~g}$ Remazol dye together with $50 \mathrm{~g} \mathrm{Na}_{2} \mathrm{SO}_{4}$ and $5.0 \mathrm{~g} \mathrm{Na}_{2} \mathrm{CO}_{3}$ per liter of solution was prepared. Four dye baths were prepared for different Remazol dyes such as Rot R, Dark Blue, Schwarz RL and Blue BB. Preparation process was repeated with alum in four dye baths.

\subsubsection{Preparation of a peripheral blood film}

The slides were cleaned with $70 \%$ ethyl alcohol and allowed to dry. The middle or ring finger was selected to make a hole. The area was cleaned with $70 \%$ ethyl alcohol and punctured. A drop of blood was placed on to a clean slide. The blood was then spread on the glass slide by another slide. This was repeated with several slides. The slides were dried and fixed with methyl alcohol ${ }^{16}$

\subsubsection{Dye application on HBCs}

A $1000 \mathrm{~mL}$ dye solution containing $50 \mathrm{~g} \mathrm{Na}_{2} \mathrm{SO}_{4}$ and $5.0 \mathrm{~g} \mathrm{Na}_{2} \mathrm{CO}_{3}$ was distributed to beakers in portions of 100 milliliters. Four slides were submerged into each beaker. The dye solution was kept at room temperature and one slide was taken out, washed with distilled water, left to dry, examined and then the dye solution was put into the oven at $60^{\circ} \mathrm{C}$, the second slide was taken out, washed with distilled water, left to dry, and then examined. The same processes were repeated at $100^{\circ} \mathrm{C}$. While the dyeing temperature was changing, the dyeing time was also changed as 15, 30, 45, and 60 minutes. During changing times, one of the slides was taken out from the dye solution, washed with distilled water, left to dry, and examined. These processes were applied to only one Remazol dye solution. Then, the same processes were also applied to the other three Remazol dyes. In the second step, $0.1 \%$ Remazol Rot R solution was prepared in a beaker. Mordants are commercially available, commonly in the form of salts containing metals such as chrome, copper, tin, iron, and aluminum. Other types of mordants which are non-metal mordants are tannins, cream of tartar, baking soda and vinegar ${ }^{17,18}$. One of the beakers was left empty, while the other one was loaded with 2.0 grams of alum mordant $\left(\mathrm{KAl}\left(\mathrm{SO}_{4}\right)_{2} .12 \mathrm{H}_{2} \mathrm{O}\right)$ and mixed with a glass stirrer. Mordant is added to the dye solution to influence it, it does not serve as a color source on its own. The cell is impregnated with the mordant, then during the dyeing process, the dye reacts with the mordant, forming a chemical bond and attaching it firmly to the cell. Two slides were submerged 63 | $\mathrm{P}$ a g e 
into each beaker. They were kept at $100^{\circ} \mathrm{C}$ for an hour in an oven and then the slides were taken from the solution, washed with distilled water, and left to dry. Photographs of the HBCs on all dried slides were taken at 1000 magnifications by microscopy.

\section{Results}

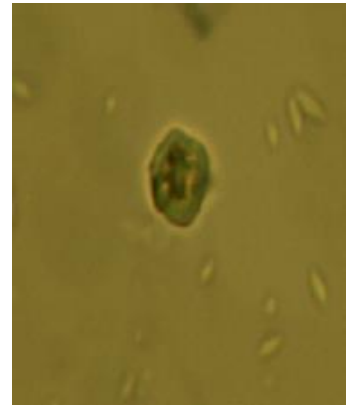

(a)

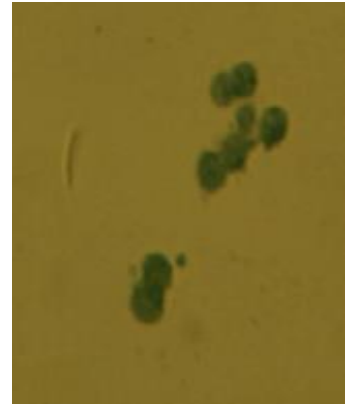

(b)

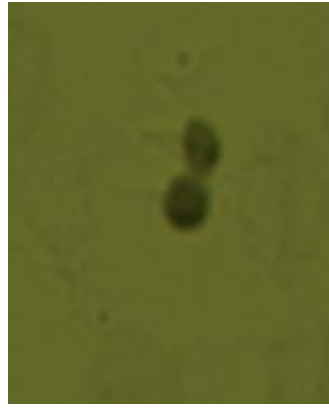

(c)

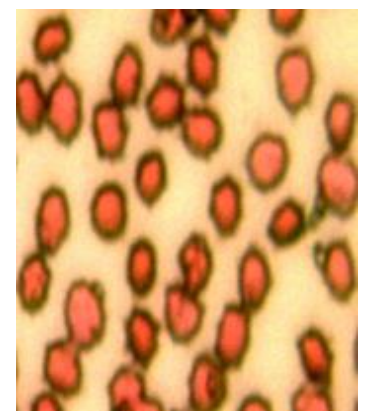

(d)

Figure 1. Photographs of $\mathrm{HBCs}$ stained at $100^{\circ} \mathrm{C}$, for 60 minutes with $\mathrm{Na}_{2} \mathrm{SO}_{4} / \mathrm{Na}_{2} \mathrm{CO}_{3}$ in solution of (a) Remazol Dark Blue, (b) Remazol Blue BB, (c) Remazol Schwarz RL, (d) Remazol Rot R

Photographs of HBCs on the slides were studied in terms of their staining. HBCs were stained with four Remazol dyes at $100^{\circ} \mathrm{C}$ for an hour. This method gave the best result. It was understood from the microscopic examination that generally, blood cells were stained a green-dark blue color by Remazol dyes only with this method. Staining with Remazol Rot R is obtained a different color, like pink. Figure 1 shows staining quality with soda-sulfate mordant.

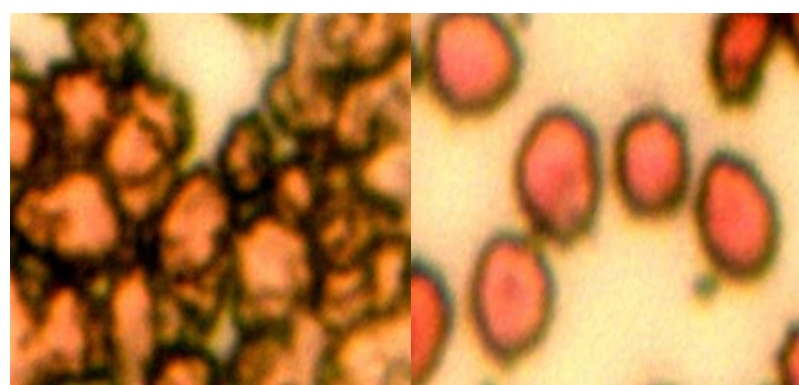

(a)

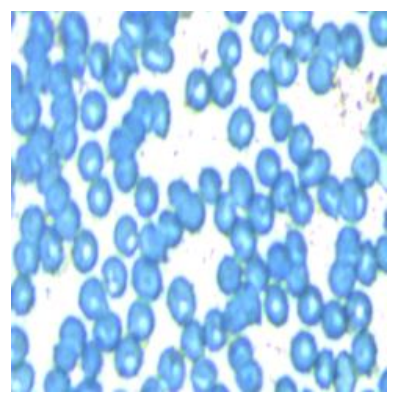

(d) (b)

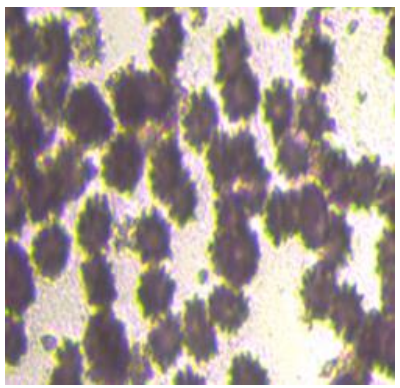

(e)

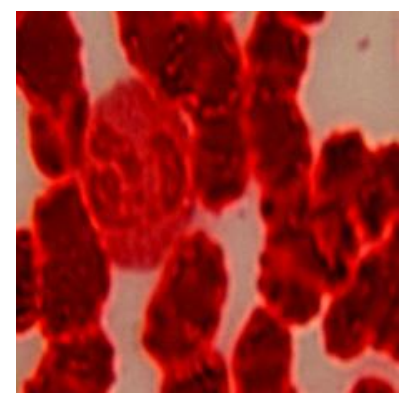

(c)

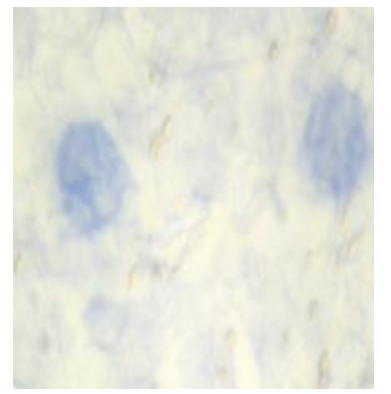

(f)

Figure 2. Photographs of blood cells stained at $100^{\circ} \mathrm{C}$, for 60 minutes in Remazol Rot R solution (a) Without mordant (b) With sodium sulfate and sodium carbonate (c) With potassium aluminum sulfate 
or alum in Remazol Rot R solution d) With alum in Remazol Blue BB solution (e) With alum in Remazol Schwarz RL solution $\mathrm{f}$ ) With alum in Remazol Dark Blue solution

Figure 2 (a) shows that there was no staining in the HBCs by the Remazol Rot R dye solution when the dyeing operation was performed at $100^{\circ} \mathrm{C}$ for 1 hour without adding salt. The same dye solution was taken in two equal volumes. Soda-sulfate was put into one volume, alum was put into another volume the slides were then put into each one, and left at $100^{\circ} \mathrm{C}$ for an hour. It is seen in Figure 2 (c) that blood cells were dyed a red color by alum, which is a salt containing metal. It is also seen in Figure 2 (b) that the cells in the solution using soda-sulfate as mordant are also dyed light pink. Figure 2 (d) that blood cells were dyed a blue color by alum in Remazol Blue BB solution. Figure 2 (e) that blood cells were dyed dark gray-black color by alum in Remazol Schwarz RL solution. Figure 2 (f) that blood cells were dyed dark blue color by alum in Remazol Dark Blue solution. In each of the three dyeings, mordants vary but temperature, duration and dye solution are constant. This condition affected the result of the dyeing very differently and positively.

\subsection{Negative Results}

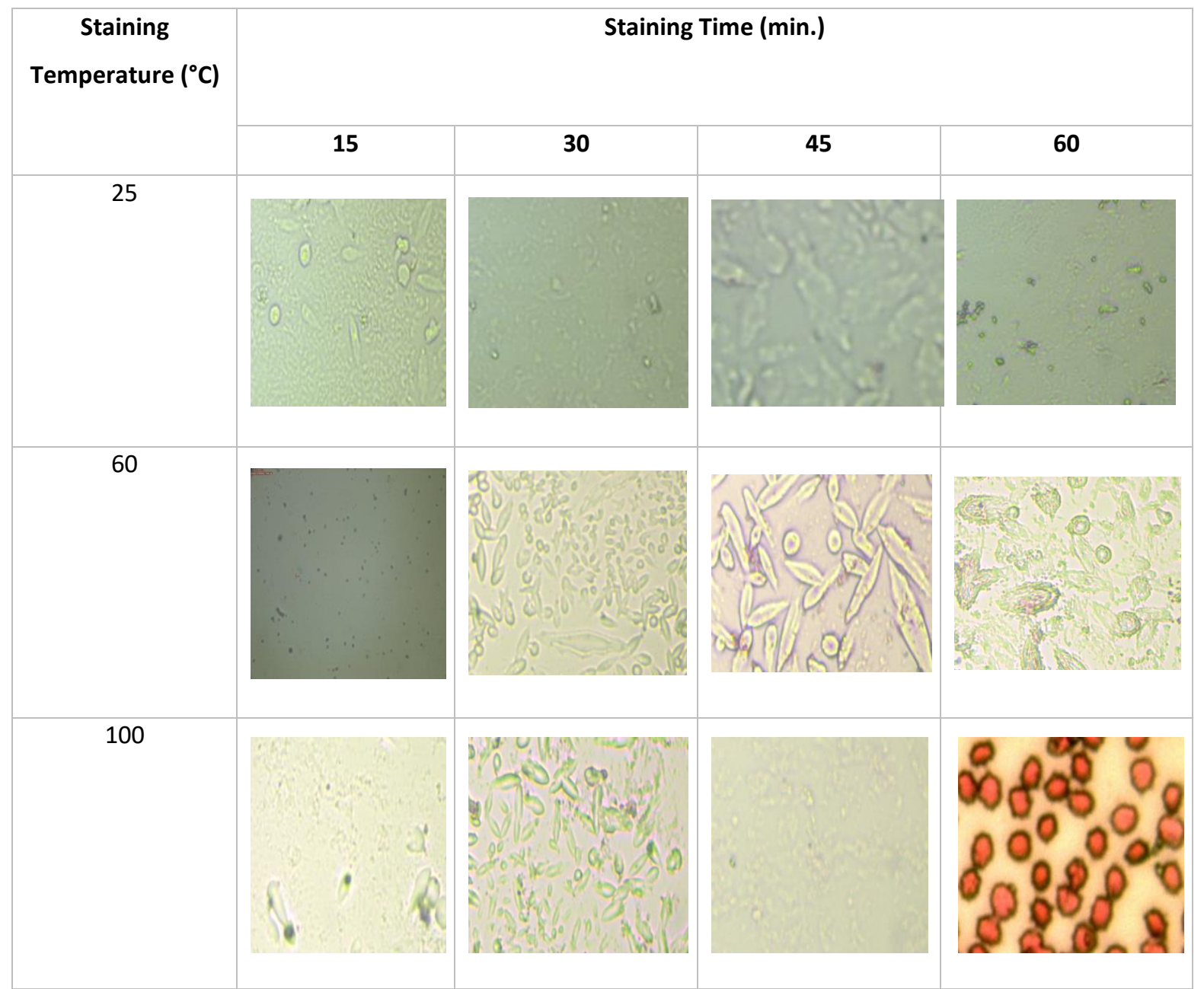

Figure 3. Photographs of HBCs stained at different temperature and time in different Reactive dyes 
HBCs were not stained with any Remazol dye solution at different temperature and staining times. These are shown in Figure 3. But positive result of HBCs staining was optained at $100^{\circ} \mathrm{C}$, for 60 minutes in Remazol Rot R solution (Fig 3).

\section{Discussion}

$\mathrm{NH}_{2}$ and $\mathrm{OH}$ groups in the structure of wool and cotton have a role in the reactive dyeing of textile materials such as wool and cotton ${ }^{19}$. Instead of weak intermolecular forces between these groups and reactive dyes occur strong covalent bonds. Thus, colored materials are obtained ${ }^{20,7}$. In the dyeing of blood cells with reactive dye, $\mathrm{NH}_{2}, \mathrm{OH}$ groups and similar structures in the cell are thought to bind with the reactive dye. This situation is seen in Figure 1 in the cells with light colors, which vary according to the color of the dye. In order to reveal the cause of the paleness in the color, we applied a reactive dyeing with mordants containing metal and without metal, so that the color of the blood cells was darker.

Metal-free salts, namely soda and sodium sulfate were added to the same dye solution, and the resulting colors of the cells are seen in Figure 2b. Also, $2 \mathrm{~g}$ alum, which contains aluminum metal was put into the same dye solution. Neutrophils and other blood cells were stained a bright, dark red color. This result is seen in Figure 2c. Therefore, when using metal-containing salts as mordants, the chelate complexes formed by the metals are more effective in increasing the color yield in the dye as shown in Figure 2. The acidity of the dye solution is increased by the alum mordant, whereas the alkalinity of the solution is changed by the soda-sulfate. Therefore, the staining color appears darker as more acidity in the dye solution affects most $\mathrm{NH}_{2}$ groups of proteins in the cell ${ }^{21}$. It is well known that the application of reactive dyes on cellulose fibers is carried out under highly alkaline conditions ${ }^{22}$. Human blood cells do not contain cellulose, therefore blood cells do not stain in alkali Remazol dyes. That is, the latter two different mordants serve to change the alkalinity and acidity, respectively, of the dye solution, another property that influences the final color. So that, blood cells were effectively dyed by four Remazol dyes with alum mordant.

Studies on cell staining with Remazol dyes and the use of alum or metal-containing mordant materials with Remazol dyes are not available in the literature. Thus, this study is the first on the subject. We believe that it will help to inspire other studies.

\section{Compliance with ethical standarts}

Conflict of interest: The author declare that they have no conflict of interest.

\section{References}

[1] Kant, R. (2012). Textile Dyeing Industry an Environmental Hazard. Natural Science 4, 22-26

[2] Wang, Z. P., Xue, M.M., Huang, K., Liu, Z.Z. (2011). Textile dyeing wastewater treatment. In P, Hauser, (eds.): Advances in Treating Textile Effluent. In Tech Inc Croatia, 91-116

[3] Yi, L., Jiao, W., Chen, X., Chen, W. (2011). An overview of reclaimed waterreuse in China. J Environ Science, 23, 1585-1593

[4] Kim, T.H., Park, C., Yang,J,, Kim, S. (2004). Comparison of disperse and reactive dye removals by chemical coagulation and Fenton oxidation. J Hazardous Materials, 112, 95-103

[5] Panswad, T., Luangdilok, W. (2000). Decolorization of reactive dyes with different molecular structures under different environmental conditions. Water Res 34, 4177-4184

[6] Caldwell, J.B., Milligan, B. (1963). Reactive Dyes Related to the Remazol Class. Tex Res Journal, 6, 481-487

[7] Ojstrsek, A., Doliska, A., Fakin, D. (2008). Analysis of reactive dyestuffs and their hydrolysis by capillary electrophoresis. Anal Science, 24, 1581-1587

66 | P a g e

www.iiste.org 
[8] Matyjas, E., Rybicki, E. (2003). Novel reactive red dyes. Autex Res. Journal 3, 93-95

[9] Siroky, J., Blackburn, R.S., Bechtold, T., Taylor, J., White, P. (2011). Alkali treatment of cellulose II fibres and effect on dye sorption. Carbohyd Polym, 84, 299-307

[10] Gurr, E. (1971). Synthetic Dyes in Biology, Medicine and Chemistry. Academic Press London and New York 15-540

[11] Titford, M., Grubler, G., Hollborn, K. (1993). Two founders of the biological stain industry. J Histotechnology 16, 155-158

[12] Wolf D, Kuhlmann MD Dyes, stains, and special probes in histology. Division of Radiooncology Deutsches Krebsforschungszentrum 69120 Heidelberg Germany

[13] (http://www.immunologielabor.com/cellmarker_files/IET introduct_05.pdf) (23/4/2018a)

[14] Wolf D, Kuhlmann MD Natural and synthetic dyes in histology. Division of Radiooncology, Deutsches Krebsforschungszentrum, $69120 \quad$ Heidelberg, Germany. (http://www.immunologielabor.com/cellmarker_files/IET_reagents_07.pdf)

[15] Vankar, P.S., Shankar, R., Wijayapala, S. (2009). Dyeing Cotton, Silk and Wool Yarn with Extract of Garniciamangostana Pericarp. J Tex App Tech Men 6, 1-3 (23/4/2018b)

[16] Samanta, A.K., Agarwal, P. (2009). Application of Natural Dyes on Textiles. Ind J Fib Tex Res, 34,384-399

[17] Adewoyin, A.S. (2014). Peripheral Blood Film-A Review. Annals of Ibadan Postgraduate Medicine, 12, 71-9

[18] Davulcu, A., Benli, H., Sen, Y., Bahtiyari, M.İ. (2014). Dyeing of cotton with thyme and pomegranate peel. Cellulose, 21, 4671-4680

[19] Siva, R. (2007). Status of Natural Dyes and Dye Yielding Plants in India. Current Science, 92

[20] Cook, J.G.(1993). Handbook of textile fibres. I. Natural fibres, $5^{\text {rd }}$, Merrow Durham England, 79-132

[21] Hunger, K. (2003). Industrial Dyes: Chemistry, Properties, Applications. Wiley-VCH Verlag GmbH and Co., Weinheim Germany, 1-12

[22] Shavandi, A., Silva, T.H., Bekhit, A.A., Bekhit, A.E.A. (2017). Keratin dissolution, extraction and biomedical application. Biomater Science, 5, 1699-1735

[23] Waring, D.R. (1990). Dyes for Cellulosic Fibers. In Waring D. R, Hallas G (eds): The Chemistry and Application of Dyes. Plenum Press New York, 49-62 